\title{
Carbonization Characteristics of Juvenile Woods from Some Tropical Trees Planted in Indonesia
}

\section{Hidayat, Wahyu}

Laboratory of Biomaterial Design, Division of Sustainable Bioresource Science, Department of Agro-environmental Sciences, Faculty of Agriculture, Kyushu University I College of Forest and Environmental Sciences, Kangwon National University | Department of Forestry, Faculty of Agriculture, Lampung University

Qi, Yue

Laboratory of Biomaterial Design, Division of Sustainable Bioresource Science, Department of Agro-environmental Sciences, Faculty of Agriculture, Kyushu University | College of Forest and Environmental Sciences, Kangwon National University

Jang, Jae-Hyuk

Laboratory of Biomaterial Design, Division of Sustainable Bioresource Science, Department of Agro-environmental Sciences, Faculty of Agriculture, Kyushu University | College of Forest and Environmental Sciences, Kangwon National University

Febrianto, Fauzi

Laboratory of Biomaterial Design, Division of Sustainable Bioresource Science, Department of Agro-environmental Sciences, Faculty of Agriculture, Kyushu University | Department of Forest Products, Faculty of Forestry, Bogor Agricultural University

他

https://doi.org/10.5109/1801799

出版情報：九州大学大学院農学研究院紀要. 62 (1)，pp. 145-152，2017-02-24. Faculty of Agriculture, Kyushu University

バージョン :

権利関係 : 


\title{
Carbonization Characteristics of Juvenile Woods from Some Tropical Trees Planted in Indonesia
}

\author{
Wahyu HIDAYAT ${ }^{1,2}$, Yue QI ${ }^{1}$, Jae-Hyuk JANG ${ }^{1}$, Fauzi FEBRIANTO ${ }^{3}$, Seung-Hwan LEE ${ }^{1}$, \\ Hee-Mun CHAE $^{1}$, Tetsuo KONDO and Nam-Hun KIM ${ }^{1 *}$
}

\author{
Laboratory of Biomaterial Design, Division of Sustainable Bioresource Science, \\ Department of Agro-environmental Sciences, Faculty of Agriculture, \\ Kyushu University, Fukuoka 812-8581, Japan \\ (Received November 4, 2016 and accepted November 4, 2016)
}

\begin{abstract}
The objective of this study was to evaluate the characteristics of charcoals from juvenile woods of albizia (Paraserianthes falcataria), gmelina (Gmelina arborea), mindi (Melia azedarach), and mangium (Acacia mangium). Carbonization was performed at 400,600, and $800^{\circ} \mathrm{C}$ for 10 min with a heating rate of $6^{\circ} \mathrm{C} / \mathrm{min}$. The physical, bioenergetic, and chemical properties were evaluated. Maximum char yield was obtained at $400^{\circ} \mathrm{C}$ and the increase of carbonization temperature resulted in a decrease of char yield. At the same carbonization temperature, char yield was higher in wood with greater initial density, i.e. ordered from the highest to the lowest: mangium, mindi, gmelina, and albizia. The heating values in all woods increased after carbonization, with maximum values at $600^{\circ} \mathrm{C}$. Maximum energy densification ratio and energy yield were obtained at carbonization temperature of $600^{\circ} \mathrm{C}$ and $400^{\circ} \mathrm{C}$, respectively. Char yield of $23.62-39.03 \%$, heating value of $25.16-33.85 \mathrm{~kJ} / \mathrm{g}$, energy densification ratio of $1.45-1.72$, energy yield of $39.09-60.10 \%$, ash content of $0.80-3.94 \%$, volatile matter of $14.61-38.69 \%$, and fixed carbon of $58.58-$ $83.27 \%$ were obtained in all charcoals from juvenile woods and were comparable with those of mature woods, showing suitability for the production of charcoal fuel.
\end{abstract}

Key words: carbonization, juvenile wood, tropical species, heating value, proximate analysis

\section{INTRODUCTION}

The demand for forest products continues to rise as world population and incomes grow (FAO, 2014). These demands will have to be met from a static or declining resource. Countries deal with this challenge in many different ways, including the application of a mix of approaches aiming at broadly promoting sustainable forest management and land use planning. In addition, there have been improvements in harvesting and processing technologies and increases in plantation establishment.

Planted forests play a very important role in providing wood supply in Indonesia. In 2013, 19.55 million m3 out of the total 23.23 million $\mathrm{m}^{3}$ of wood supplied came from planted forests (Ministry of Forestry, Republic of Indonesia, 2014). In Indonesia, planting fast growing tree species has been widely established in industrial, stateowned enterprise, and community planted forests.

Albizia (Paraserianthes falcataria), gmelina (Gmelina arborea), mindi (Melia azedarach), and mangium (Acacia mangium) are promising fast growing tree species to be developed for industrial planted forests and community forests. Albizia is one of the most important pioneer multipurpose tree species, and it is preferred for industrial forest plantations in Indonesia due to its very fast growth, ability to grow on various soil

${ }^{1}$ College of Forest and Environmental Sciences, Kangwon National University, Chuncheon 24341, Republic of Korea

2 Department of Forestry, Faculty of Agriculture, Lampung University, Bandar Lampung 35145, Indonesia

${ }^{3}$ Department of Forest Products, Faculty of Forestry, Bogor Agricultural University, Bogor 16680, Indonesia

* Corresponding author: (E-mail: kimnh@kangwon.ac.kr) conditions, and its favorable silvicultural characteristics (Krisnawati et al., 2011). Gmelina is indigenous to India and neighboring countries and planted in many tropical countries. Moreover, it can adapt to various soil conditions and is known to improve soil through nitrogen fixation (Allen and Allen, 1981). Mindi has been introduced in commercial plantations in Indonesia, particularly in state-owned enterprises plantation areas and community forests, as it is well adapted to warm climates, poor soils, and seasonally dry conditions (Harrison et al., 2003). Mangium has become the most abundant tree species in forestry plantation programs in Southeast Asia. In Indonesia, the total area of mangium tree plantations reached more than 1 million ha (Yamashita et al., 2008). Mangium is characterized as a fast growing species, adaptable to a wide range of acidic soils ( $\mathrm{pH} 4.5-6.5$ ), with a tolerance for low fertility and impeded drainage in devastated sites (Awang and Taylor, 1993).

In our previous studies, we have reported on the properties of those four tropical species including their anatomical characteristics (Kim et al., 2012), physical and mechanical properties (Kim et al., 2014), combustion properties (Park et al., 2015), natural durability properties (Febrianto et al., 2015), and weathering (ultraviolet radiation) properties (Park et al., 2016). The results showed that those four species have relatively low density, low durability, and low mechanical properties that are not suitable for structural timbers. Forest industry sectors should be encouraged to adapt to the use of the species from planted forests. One of the technologies that might be suitable for this is carbonization.

Carbonization is defined as the pyrolysis process in inert atmosphere by which high carbon content solid resi- 
dues are formed from organic material (McNaught and Wilkinson, 1997). During the thermal decomposition process, moisture and volatiles are removed, leaving a solid residue (charcoal), liquids (condensable vapors), and permanent gases (Lohri et al., 2016).

Charcoal can be utilized for a broad range of applications including as an alternative source of domestic and industrial energy for briquettes, firewood, gas, coal, and electricity. Charcoal can be manufactured from various lignocellulosic materials. However, not all species can produce good quality charcoal due to variability in physical properties (e.g., density, moisture content, ash content, and volatile matter) and chemical composition (i.e., cellulose, hemicelluloses, and lignin) (Kumar and Chandrashekar, 2013; Collard and Blin, 2014; Lohri et al., 2016). In addition, charcoal quality is affected by process parameters such as carbonization temperature, heating rate, residence time, sample size, and reactor pressure (Antal et al., 2000; Kim and Hanna, 2006; Kwon et al., 2009; Yan et al., 2009). Comprehensive study on carbonization of juvenile woods from fast-growing tree species is very limited (Fuwape, 1996; Pereira et al., 2013; Marques et al., 2015). In this context, the objective of this study is to evaluate the charcoal characteristics of juvenile woods from four different tropical fast-growing tree species, after carbonization at different temperatures.

\section{MATERIALS AND METHODS}

\section{Materials}

Juvenile woods of four tropical fast growing species i.e., albizia, gmelina, mindi, and mangium were obtained from experiment plots in the plantation sites of Perum Perhutani, a state-owned enterprise in Indonesia. The first experiment plot, located in Purwakarta consists of mix plantation of albizia and mindi. The second experiment plot, located in Bogor consists of mix plantation of gmelina and mangium. To provide optimal growth, 30 trees of each species were planted with a spacing of $3 \mathrm{~m}$ $\times 3 \mathrm{~m}$ in both experiment plots. The trees of the four species were felled and disks of $70 \mathrm{~mm}$ thickness were obtained at the diameter at breast height (DBH). Wood disks were air-dried and kept in a conditioning room under the relative humidity of $65 \pm 3 \%$ and a temperature of $25 \pm 2{ }^{\circ} \mathrm{C}$ before the experiment. Disks were cut into small blocks of $40 \mathrm{~mm}$ (length) $\times 20 \mathrm{~mm}$ (width) $\times$ $20 \mathrm{~mm}$ (thickness). The obtained blocks were oven dried at $105^{\circ} \mathrm{C}$ for $24 \mathrm{~h}$ prior to carbonization process. General information about the four species used in this study is shown in Table 1.

\section{Methods}

\section{Carbonization of Woods}

Wood samples were carbonized in an electric furnace (HT 16/16, Supertherm, Germany) using nitrogen gas with a concentration of $1 \mathrm{~kg} / \mathrm{cm}^{2}$. The carbonization was performed with a heating rate of $6^{\circ} \mathrm{C} / \mathrm{min}$ from ambient temperature to the target temperatures of 400, 600, and $800^{\circ} \mathrm{C}$. After the target temperature was attained, it was maintained for $10 \mathrm{~min}$ and the charcoal samples were rapidly taken out of the furnace and buried in a sand container until it cooled down.

Charcoal Characterization

To evaluate the bioenergy property, char yield, energy densification ratio, and energy yield were determined using the following equations (Yan et al., 2009):

$$
\begin{aligned}
\text { Char yield }= & \frac{\text { Oven dried weight of carbonized wood }}{\text { Oven dried weight of origin wood }} \\
& \times 100 \%
\end{aligned}
$$

Energy densification ratio

$$
=\frac{\text { Heating value of carbonized wood }}{\text { Heating value of origin wood }}
$$

Energy yield $=$ Char yield $\times$ Energy densification ratio

The heating value of woods before and after carbonization was measured in an oxygen bomb calorimeter (Parr 6300 calorimeter, Parr Instrument) according to Korean Standard KS E 3707 (KSA 2011). Powder sam-

\begin{tabular}{|c|c|c|c|c|}
\hline Wood species & $\begin{array}{l}\mathrm{DBH}^{\mathrm{a}} \\
(\mathrm{cm})\end{array}$ & $\begin{array}{c}\text { Age } \\
\text { (year) }\end{array}$ & $\begin{array}{l}\text { Density } \\
\left(\mathrm{g} / \mathrm{cm}^{3}\right)\end{array}$ & Origin \\
\hline $\begin{array}{l}\text { Albizia } \\
\text { (P. falcataria) }\end{array}$ & $\begin{array}{c}16.5 \\
(1.72)\end{array}$ & 7 & $\begin{array}{c}0.22 \\
(0.01)\end{array}$ & $\begin{array}{l}\text { Purwakarta, Indonesia } \\
\left(6^{\circ} 29^{\prime} 59^{\prime \prime} \mathrm{S}, 107^{\circ} 21^{\prime} 37^{\prime \prime} \mathrm{E}\right)\end{array}$ \\
\hline $\begin{array}{l}\text { Gmelina } \\
\text { (G. arborea) }\end{array}$ & $\begin{array}{c}16.1 \\
(1.82)\end{array}$ & 6 & $\begin{array}{c}0.34 \\
(0.02)\end{array}$ & $\begin{array}{l}\text { Bogor, Indonesia } \\
\left(6^{\circ} 20^{\prime} 21^{\prime \prime} \mathrm{S}, 106^{\circ} 33^{\prime} 58^{\prime \prime} \mathrm{E}\right)\end{array}$ \\
\hline $\begin{array}{l}\text { Mindi } \\
\text { (M. azedarach) }\end{array}$ & $\begin{array}{c}15.4 \\
(2.01)\end{array}$ & 7 & $\begin{array}{c}0.48 \\
(0.03)\end{array}$ & $\begin{array}{l}\text { Purwakarta, Indonesia } \\
\left(6^{\circ} 29^{\prime} 59^{\prime \prime} \mathrm{S}, 107^{\circ} 21^{\prime} 37^{\prime \prime} \mathrm{E}\right)\end{array}$ \\
\hline $\begin{array}{l}\text { Mangium } \\
\text { (A. mangium) }\end{array}$ & $\begin{array}{c}17.7 \\
(1.17)\end{array}$ & 6 & $\begin{array}{c}0.56 \\
(0.02)\end{array}$ & $\begin{array}{l}\text { Bogor, Indonesia } \\
\left(6^{\circ} 20^{\prime} 21^{\prime \prime} \mathrm{S}, 106^{\circ} 33^{\prime} 58^{\prime \prime} \mathrm{E}\right)\end{array}$ \\
\hline
\end{tabular}
ples of $0.4-0.6 \mathrm{~g}$ after 60 mesh sieving were oven dried

Table 1. General information of the woods used in this study

Numbers in parenthesis are standard deviations.

${ }^{a}$ means are average of three trees measurement.

${ }^{\mathrm{b}}$ oven dry density = oven dried mass/oven dried volume, means are average of five replications. 
at $105^{\circ} \mathrm{C}$ for $24 \mathrm{~h}$ and used for the analysis.

The $\mathrm{pH}$ was determined using a mixed solution of 1 g oven-dried wood charcoal powder and $100 \mathrm{ml}$ distilled water in accordance with TAPPI 435 (TAPPI 2006). The solution was then boiled for 10 min and cooled down until reaching room temperature. $\mathrm{pH}$ was measured with a $\mathrm{pH}$ meter (InoLab pH Level 2).

For proximate analysis, volatile matter and ash content were evaluated in accordance with KS E ISO562 (KSA 2012a) and KS E ISO1171 (KSA 2012b), respectively. In addition, fixed carbon content was calculated using the equation:

$$
\% \mathrm{FC}=100-(\% \text { Ash }+\% \mathrm{VM})
$$

where \%FC, \%Ash, and \%VM, mean the mass percentages of fixed carbon, ash, and volatile matter of the sample, respectively. Char yield, heating value, $\mathrm{pH}$, volatile matter, ash content, and fixed carbon content were measured in five replications.

Changes of the surface chemical properties during carbonization were evaluated with FTIR spectroscopy. FTIR spectra of wood and charcoal samples were measured by direct transmittance using a $\mathrm{KBr}$ pellet. Pellets were made by intimately mixing $2 \mathrm{mg}$ of wood or charcoal powder with $100 \mathrm{mg}$ of dry $\mathrm{KBr}$. Spectra were scanned in the range of $4000-400 \mathrm{~cm}^{-1}$ using a Spectrum 100 FTIR spectrometer (PerkinElmer Inc., USA) at a spectral resolution of $4 \mathrm{~cm}^{-1}$ and 4 scans were taken per sample.

\section{RESULTS AND DISCUSSION}

\section{Char Yield}

The char yields of the four studied juvenile woods after carbonization at different temperatures are shown in Figure 1. The char yields at $400^{\circ} \mathrm{C}$ ranged from 31.22 to $39.03 \%$ and decreased gradually with increasing carbonization temperature, reaching the lowest char yields of $23.62-27.77 \%$ at $800^{\circ} \mathrm{C}$ in all species. The results showed differences in char yields among the four species. It was highest in mangium and in order of mindi, gmelina, and albizia. This may be due to the differences in the

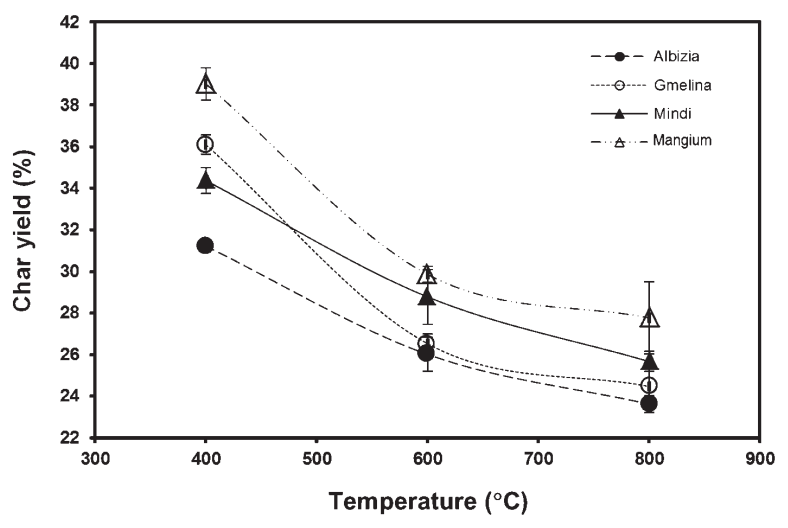

Fig. 1. Char yield of juvenile woods from four tropical wood species after carbonization at 400,600 , and $800^{\circ} \mathrm{C}$. physical properties and chemical composition. For example, mangium has the highest density among the other species. Previous studies also reported that high-density wood species generally resulted in higher char yield compared to low-density wood (Fuwape et al., 1997; Cutter and McGinnes, 1981).

The obtained char yields of the four juvenile woods in this study were similar to those of other juvenile woods (Fuwape, 1996; Pereira et al., 2013) and comparable with those of the mature woods reported by Kim and Hanna (2006) and Kwon et al. (2009). According to Fuwape (1996), the char yields of juvenile wood from gmelina (5-year-old) after carbonization at 400 and $600^{\circ} \mathrm{C}$ were 32.2 and $18.9 \%$, respectively. Kim and Hanna (2006) reported on the carbonization of mature wood from Querqus variabilis and obtained char yields of $25.6,18.7$, and $16.6 \%$, after carbonization at 400, 600, and $800^{\circ} \mathrm{C}$, respectively.

A higher char yield at $400^{\circ} \mathrm{C}$ can be attributed to a limited decomposition and degradation of the main chemical constituents of wood (i.e., cellulose, hemicellulose, and lignin) in this temperature, when compared with that at 600 and $800^{\circ} \mathrm{C}$. During thermal decomposition, hemicellulose was the first degraded component at a temperature of $220-315^{\circ} \mathrm{C}$, followed by cellulose at 315 $400^{\circ} \mathrm{C}$, while lignin decomposed slowly, reaching maximum decomposition rate at above $900^{\circ} \mathrm{C}$ (Yang et al., 2007). The decrease of char yield may also be due to the higher magnitude of volatile matter removal from charcoal as the carbonization temperature increased (Table 2).

The overall results of char yield after carbonization at 400,600 , and $800^{\circ} \mathrm{C}$ with a range of $24-40 \%$ can be considered satisfactory. Generally, the average commercial char yield does not exceed 30\% and is affected by the raw material and conversion process used (Antal et al., 2000).

\section{Heating Value}

Heating value expresses the energy content released when wood is burned in the air, which is very important in determining the potential of charcoal for bioenergy. Figure 2 shows the heating value before and after carbonization at different temperatures. The heating values for albizia, gmelina, mindi, and mangium before carbonization were quite similar, showing $19.12-19.78 \mathrm{~kJ} / \mathrm{g}$, which is higher than the heating value of gmelina $(16.61 \mathrm{~kJ} / \mathrm{g})$. The variation in heating values can be attributed to the different chemical composition of the wood, especially in lignin content. Kaltschmitt et al. (2009) reported that lignin has a heating value of $27.0 \mathrm{~kJ} / \mathrm{g}$, remarkably higher than cellulose and hemicelluloses with values of 17.3 and $16.2 \mathrm{~kJ} / \mathrm{g}$, respectively. Therefore, the higher lignin content will result in a higher heating value (Demirbas, 2003; Kataki and Konwer, 2001). Previous studies reported that albizia, mindi, and mangium have lignin content of 26.8, 30.1, and 24.9\%, respectively (Martawijaya et al., 1989; Awang and Taylor, 1993), whereas gmelina has a lower lignin content of $22.0 \%$ (Wu et al., 1992). This lower lignin content of gmelina may be one of the factors 
Table 2. Proximate analysis of juvenile woods from four tropical wood species before and after carbonization at 400, 600 , and $800^{\circ} \mathrm{C}$

\begin{tabular}{|c|c|c|c|c|}
\hline Wood species & $\begin{array}{l}\text { Temp. } \\
\left({ }^{\circ} \mathrm{C}\right)\end{array}$ & $\begin{array}{c}\text { Ash Content } \\
(\%)\end{array}$ & $\begin{array}{c}\text { Volatile Matter } \\
\text { (\%) }\end{array}$ & $\begin{array}{c}\text { Fixed Carbon } \\
(\%)\end{array}$ \\
\hline \multirow{4}{*}{$\begin{array}{l}\text { Albizia } \\
\text { (P. falcataria) }\end{array}$} & Control & $1.03(0.11)$ & $73.81(3.04)$ & $25.16(3.05)$ \\
\hline & 400 & $2.49(0.19)$ & $33.50(3.67)$ & $64.01(3.64)$ \\
\hline & 600 & $2.75(0.08)$ & $22.33(2.02)$ & $74.92(3.00)$ \\
\hline & 800 & $3.42(0.31)$ & $18.82(1.56)$ & $77.76(2.33)$ \\
\hline \multirow{4}{*}{$\begin{array}{l}\text { Gmelina } \\
(G . \text { arborea })\end{array}$} & Control & $0.61(0.04)$ & $76.82(4.82)$ & $22.57(5.10)$ \\
\hline & 400 & $2.73(0.04)$ & 38.69 (3.15) & $58.58(3.22)$ \\
\hline & 600 & $3.03(0.19)$ & $26.14(2.84)$ & $70.83(2.79)$ \\
\hline & 800 & $3.94(0.28)$ & $22.52(2.18)$ & 73.54 (2.33) \\
\hline \multirow{4}{*}{$\begin{array}{l}\text { Mindi } \\
\text { (M. azedarach) }\end{array}$} & Control & $0.57(0.08)$ & $69.65(1.86)$ & $29.78(2.04)$ \\
\hline & 400 & $0.80(0.12)$ & $28.84(1.77)$ & 70.36 (1.98) \\
\hline & 600 & $1.58(0.10)$ & $18.77(4.28)$ & 79.65 (3.67) \\
\hline & 800 & $2.12(0.12)$ & $14.61(3.54)$ & $83.27(3.67)$ \\
\hline \multirow{4}{*}{$\begin{array}{l}\text { Mangium } \\
\text { (A. mangium) }\end{array}$} & Control & $0.68(0.11)$ & $70.80(3.18)$ & $28.52(2.95)$ \\
\hline & 400 & $1.42(0.11)$ & $30.52(3.90)$ & $68.06(3.78)$ \\
\hline & 600 & $1.71(0.16)$ & $26.60(2.51)$ & $71.69(2.45)$ \\
\hline & 800 & $1.91(0.07)$ & $16.72(1.77)$ & $81.37(1.58)$ \\
\hline
\end{tabular}

Numbers in parenthesis are standard deviations. Means are average of five replications.

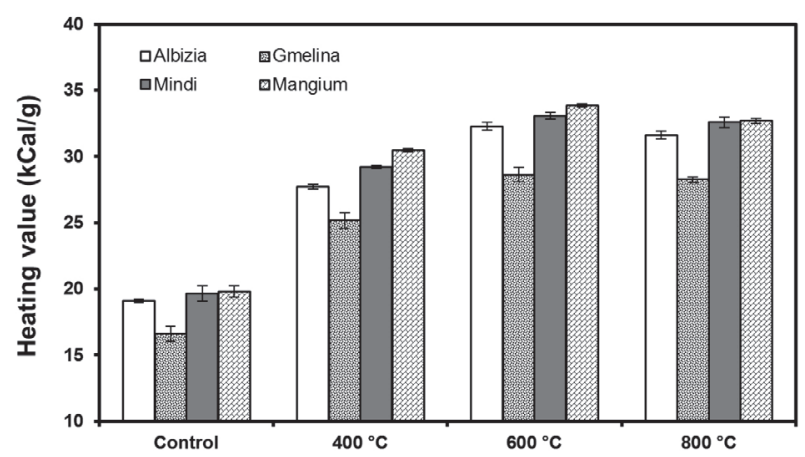

Fig. 2. Heating value of juvenile woods from four tropical wood species before carbonization (control) and after carbonization at 400,600 , and $800^{\circ} \mathrm{C}$.

for the lower heating value compared to the other studied species.

The heating values at $400^{\circ} \mathrm{C}$ increased to $25.16-$ $30.46 \mathrm{~kJ} / \mathrm{g}$, which are $42-54 \%$ higher than those of the control sample before carbonization. Its values further increased to $28.63-33.85 \mathrm{~kJ} / \mathrm{g}$ with increase in carbonization temperature to $600^{\circ} \mathrm{C}$, which are $11-16 \%$ higher than those at $400^{\circ} \mathrm{C}$. However, the heating values at $800^{\circ} \mathrm{C}$ were similar or slightly lower compared with those at $600^{\circ} \mathrm{C}$. This indicates that $600^{\circ} \mathrm{C}$ is the optimum carbonization temperature of the investigated temperature range regarding to heating values. The obtained heating values in this study were comparable to $24.70,30.98$, and $33.61 \mathrm{~kJ} / \mathrm{g}$ of the charcoals from mature wood of $Q$. variabilis after carbonization at 340,540 , and $740^{\circ} \mathrm{C}$ respec- tively (Kwon et al., 2013), even though the charcoal of the current study is from juvenile woods.

Based on the heating values, gmelina has a calorific value of $11-17 \%$ lower than the other juvenile woods. Overall, the heating values of the four juvenile woods carbonized at different temperatures meet the requirement (minimum heating value of $8 \mathrm{~kJ} / \mathrm{g}$ ) of the Indonesian Standard SNI 01-1506-1989 as the Standard of Wood Charcoal for Metal Smelting (BSN 1989).

In general, the heating value increases with carbonization showing a linear relationship with the increase of carbon content. During carbonization, volatile matter such as $\mathrm{H}_{2} \mathrm{O}, \mathrm{CO}, \mathrm{CO}_{2}$, and $\mathrm{CH}_{4}$ are released, resulting in the increase of the fixed carbon content (Han and Kim, 2006; Kumar et al., 2013; Liu et al., 2014). Furthermore, increasing carbonization temperature resulted in the decrease of volatile matter and the increase of the fixed carbon content.

The present results of proximate analysis are in good agreement with the previous studies mentioned above. As summarized in Table 2, ash content and volatile matter were significantly increased and decreased respectively with increasing carbonization temperature, resulting in the increase of fixed carbon content. Similar to the heating values, the fixed carbon content of the control sample greatly increased as the temperature increased to $400^{\circ} \mathrm{C}$, and slightly increased from $600^{\circ} \mathrm{C}$ to $800^{\circ} \mathrm{C}$. The result of the proximate analysis in this study is similar to the previous study of Marquez et al. (2015) who reported that carbonization of 5-year-old A. mangium woods at $400^{\circ} \mathrm{C}$ resulted in ash content of $1.64 \%$, vola- 
tiles of $34.17 \%$, and fixed carbon of $64.19 \%$.

Table 3 summarizes energy densification ratio and energy yield. Energy densification ratio and energy yield after carbonization were determined from the heating value data. In all species, the increase in temperature caused a reduction in energy yields. On the other hand, energy densification ratio increased with increasing temperature. Energy densification ratio showed a similar trend with the heating value, and the highest ratio was obtained at carbonization of $600^{\circ} \mathrm{C}$. For example, albizia yields a higher energy densification ratio and energy yield than mindi at all temperatures. Carbonization of albizia at $600^{\circ} \mathrm{C}$ had a char yield of $26.01 \%$, resulting in an energy yield of $43.74 \%$, while the char yield of mindi after carbonization at $800^{\circ} \mathrm{C}$ was $25.67 \%$, resulting in energy yield of $42.55 \%$.

\section{pH Change}

Figure 3 shows pH values before and after carbonization at different temperatures. The $\mathrm{pH}$ increased with increasing carbonization temperatures. The $\mathrm{pH}$ of all samples was changed into basic after carbonization at a temperature higher than $400^{\circ} \mathrm{C}$. Generally, the lower temperatures result in a lower $\mathrm{pH}$, because the lower temperature may retain the carboxyl and hydroxyl groups in the char structure. Kwon et al. (2013) reported that $\mathrm{pH}$ value increased with increasing carbonization temperature, showing a pH of 5.5 and 9.1 at $300^{\circ} \mathrm{C}$ and $740^{\circ} \mathrm{C}$, respectively. Luo et al. (2011) reported that $\mathrm{pH}$ became weakly basic $(\mathrm{pH}=7.81)$ after carbonization at $350^{\circ} \mathrm{C}$, whereas it turned to be strongly basic $(\mathrm{pH}=$

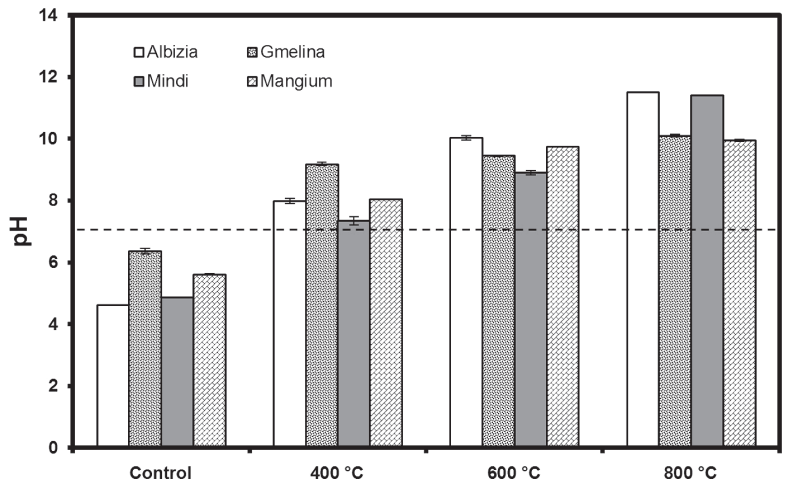

Fig. 3. pH of juvenile woods from four tropical wood species before carbonization (control) and after carbonization at 400,600 , and $800^{\circ} \mathrm{C}$.

10.80) at the higher temperature of $700^{\circ} \mathrm{C}$.

Maximum $\mathrm{pH}$ in this study was obtained after carbonization at $800^{\circ} \mathrm{C}$, showing $\mathrm{pH}$ values of $11.50,10.10$, 11.40, and 9.95, for albizia, gmelina, mindi, and mangium respectively. The basic $\mathrm{pH}$ of charcoal could positively influence the soil by increasing its cation exchange capacity (CEC). When charcoal is added to soil, it can neutralize the soil acidity, thus providing suitable conditions for microorganisms (Fowles, 2007; Luo et al., 2011).

\section{Change in Chemical Composition Investigated by FTIR}

Figure 4 shows the FTIR spectra of the four juvenile woods before and after carbonization. The correspond-

Table 3. Effect of species and temperature on the energy densification ratio and energy yield

\begin{tabular}{|c|c|c|c|}
\hline Wood species & $\begin{array}{l}\text { Temp. } \\
\left({ }^{\circ} \mathrm{C}\right)\end{array}$ & $\begin{array}{c}\text { Energy densification } \\
\text { ratio }\end{array}$ & $\begin{array}{c}\text { Energy yield } \\
(\%)\end{array}$ \\
\hline \multirow{4}{*}{$\begin{array}{l}\text { Albizia } \\
\text { (P. falcataria) }\end{array}$} & Control & $\mathrm{n} / \mathrm{a}$ & $\mathrm{n} / \mathrm{a}$ \\
\hline & 400 & $1.45(0.01)$ & $45.25(0.15)$ \\
\hline & 600 & $1.69(0.00)$ & $43.92(1.45)$ \\
\hline & 800 & $1.65(0.03)$ & 39.09 (1.27) \\
\hline \multirow{4}{*}{$\begin{array}{l}\text { Gmelina } \\
\text { (G. arborea) }\end{array}$} & Control & $\mathrm{n} / \mathrm{a}$ & $\mathrm{n} / \mathrm{a}$ \\
\hline & 400 & $1.51(0.03)$ & $54.69(1.95)$ \\
\hline & 600 & $1.72(0.03)$ & $45.72(0.83)$ \\
\hline & 800 & $1.70(0.01)$ & $41.61(1.47)$ \\
\hline \multirow{4}{*}{$\begin{array}{l}\text { Mindi } \\
\text { (M. azedarac) }\end{array}$} & Control & $\mathrm{n} / \mathrm{a}$ & $\mathrm{n} / \mathrm{a}$ \\
\hline & 400 & $1.49(0.01)$ & $51.12(0.74)$ \\
\hline & 600 & $1.68(0.01)$ & $48.41(1.84)$ \\
\hline & 800 & $1.66(0.02)$ & $42.56(0.27)$ \\
\hline \multirow{4}{*}{$\begin{array}{l}\text { Mangium } \\
\text { (A. mangiu) }\end{array}$} & Control & $\mathrm{n} / \mathrm{a}$ & $\mathrm{n} / \mathrm{a}$ \\
\hline & 400 & $1.54(0.01)$ & $60.10(1.33)$ \\
\hline & 600 & $1.71(0.01)$ & $51.10(0.85)$ \\
\hline & 800 & $1.65(0.01)$ & $45.88(3.09)$ \\
\hline
\end{tabular}

Numbers in parenthesis are standard deviations. Means are average of five replications. 
ing assignments of bands are given in Table 4 based on Nishimiya et al. (1998), Muller et al. (2009), Chen et al. (2010), and Kwon et al. (2013). Carbonization at $400^{\circ} \mathrm{C}$ and $800^{\circ} \mathrm{C}$ drastically changed the chemical structure of the four tropical woods, as shown by the differences of absorption bands between woods and charcoals. For example, most of the bands in the original albizia wood were not found in the charcoal carbonized at $400^{\circ} \mathrm{C}$, leaving only few bands. Most of the main bands assigned to cellulose and hemicellulose have disappeared, while some bands for lignin aromatic ring remained (Kwon et al., 2013).

The results in this study revealed that lignin was not completely degraded after carbonization at $400^{\circ} \mathrm{C}$. However, the aromatic bands of lignin completely disappeared in the charcoal carbonized at $800^{\circ} \mathrm{C}$. These results are in good agreement with a previous report (Nishimiya et al., 1998). They studied the chemical structure change of wood and charcoal carbonized at $300^{\circ} \mathrm{C}, 600^{\circ} \mathrm{C}$, and $800^{\circ} \mathrm{C}$ and revealed that the aromatic modes associated with lignin were found in the charcoals carbonized at $300^{\circ} \mathrm{C}$ and $600^{\circ} \mathrm{C}$, but disappeared completely in the charcoal carbonized at $800^{\circ} \mathrm{C}$. A similar trend was found in gmelina, mindi, and mangium.

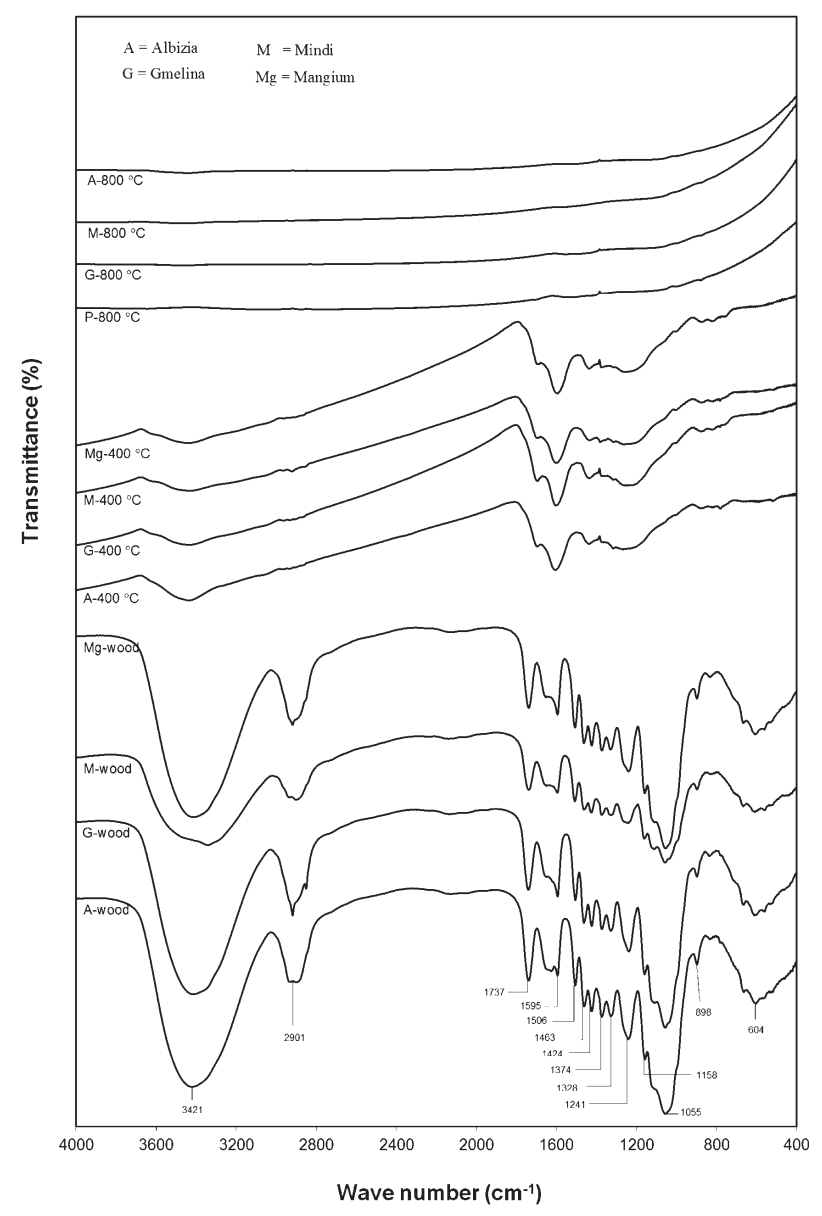

Fig. 4. FTIR spectra of juvenile woods from four tropical wood species before and after carbonization at 400 and $800^{\circ} \mathrm{C}$.

\section{CONCLUSION}

The maximum char and energy yields were obtained at a carbonization temperature of $400^{\circ} \mathrm{C}$, while the maximum heating value was obtained at a carbonization temperature of $600^{\circ} \mathrm{C}$. Proximate analysis of the charcoals showed ash content of $0.80-3.94 \%$, volatile matter of $14.61-38.69 \%$, and fixed carbon of $58.58-83.27 \%$. The obtained properties of charcoal from four juvenile tropical fast growing tree species were comparable with those of a mature wood, showing the suitability of these species for industrial (or commercial) production of charcoal.

\section{ACKNOWLEDGEMENT}

This study was carried out with the support of 'Forest Science \& Technology Projects (Project No. 2016S1100001)' provided by Korea Forest Service. The authors sincerely thank to the Korea Indonesia Forestry Cooperative (KIFC) for providing experimental sites and wood samples. The first author also would like to thanks to the Indonesian Directorate General of Higher Education (DIKTI) scholarship for funding doctoral study in Kangwon National University, South Korea since 2014 .

\section{REFERENCES}

Allen, O.N., and E. K. Allen 1981 The leguminosae: A source book of characteristics, uses and nodulation. The University of Wisconsin Press. Madison, USA.

Antal Jr., M. J., S. G. Allen, X. Dai, B. Shimizu, M. S. Tam, and M. Gronli 2000 Attainment of the theoretical yield of carbon from biomass. Industrial \& Engineering Chemistry Research 39(11): 4024-4031. DOI: 10.1021/ie000511u

Awang, K., and D. Taylor 1993 Acacia mangium, growing and utilization. MPTS Monograph Series No. 3. Winrock International and FAO. Bangkok, Thailand.

Badan Standardisasi Nasional (BSN) 1989 Indonesian Standard SNI 01-1506-1989: Standard of wood charcoal for metal smelting. National Standardization Agency. Indonesia.

Chen, H. L., C. Ferrari, M. Angiuli, J. Yao, C. Raspi, and E. Bramanti 2010 Qualitative and quantitative analysis of wood samples by Fourier transform infrared spectroscopy and multivariate analysis. Carbohydrate Polymers 82(3): 772-778. DOI: 10.1016/j.carbpol.2010.05.052

Collard, F. X., and J. Blin 2014 A review on pyrolysis constituents: mechanisms and composition of the products obtained from the conversion of cellulose, hemicellulose and lignin. Renewable and Sustainable Energy Reviews 38: 594-608. DOI: 10.1016/j.rser.2014.06.013

Cutter, B. E., and McGinnes 1981 A note on density change patterns in charred wood. Wood and Fiber Science 13(1): 39-44.

Demirbas, A. 2003 Relationships between lignin contents and fixed carbon contents of biomass samples. Energy Conversion and Management 44(9): 1481-1486. DOI: 10.1016/S01968904(02)00168-1

FAO 2014 State of the world's forests: Enhancing the socioeconomic benefits from forests. Food and Agricultural Organization of the United Nations. Rome, Italy. http://www. fao.org/3/a-i3710e.pdf

Febrianto, F., A. Z. Pranata, D. Septiana, Arinana, A. Gumilang, W. Hidayat, J. H. Jang, S. H. Lee, W. J. Hwang, and N. H. Kim 2015 Termite resistance of the less known tropical woods spe- 
Table 4. Band positions and assignments in the infrared spectra of samples before and after carbonization at 400 and $800^{\circ} \mathrm{C}$

\begin{tabular}{|c|c|c|c|c|c|c|c|c|c|c|c|c|}
\hline \multicolumn{12}{|c|}{ Wave number $\left(\mathrm{cm}^{-1}\right)$} & \multirow{3}{*}{ Band assignment } \\
\hline \multicolumn{4}{|c|}{ Wood } & \multicolumn{4}{|c|}{ Carbonized at $400^{\circ} \mathrm{C}$} & \multicolumn{4}{|c|}{ Carbonized at $800^{\circ} \mathrm{C}$} & \\
\hline A & G & M & $\mathrm{Mg}$ & A & G & M & $\mathrm{Mg}$ & A & G & M & $\mathrm{Mg}$ & \\
\hline 3421 & 3416 & 3341 & 3413 & 3433 & 3436 & 3429 & 3435 & & & & & O-H stretching \\
\hline \multirow[t]{2}{*}{2901} & 2918 & 2901 & 2919 & & & & & & & & & $\mathrm{C}-\mathrm{H}$ stretching in methyl- and methylene groups \\
\hline & 2851 & & & & & & & & & & & $\mathrm{C}-\mathrm{H}$ stretching in methyl- and methylene groups \\
\hline 1737 & 1741 & 1739 & 1739 & & 1695 & & & & & & & $\begin{array}{l}\mathrm{C}-\mathrm{O} \text { stretching in unconjugated ketone, carbonyl } \\
\text { and aliphatic groups xylan }\end{array}$ \\
\hline 1625 & & & & & & & & & & & & $\mathrm{C}-\mathrm{O}$ stretching conjugated to aromatic ring \\
\hline 1595 & 1594 & 1595 & 1595 & 1605 & 1604 & 1603 & 1595 & & & & & $\mathrm{C}-\mathrm{O}$ stretching conjugated to aromatic ring \\
\hline 1506 & 1506 & 1508 & 1506 & & & & & & & & & Aromatic skeletal stretching \\
\hline 1463 & 1463 & 1463 & 1463 & & & & & & & & & CH2 deformation stretching in lignin and xylan \\
\hline 1424 & 1424 & 1426 & 1424 & 1435 & 1436 & 1436 & 1436 & & & & & $\begin{array}{l}\text { Aromatic skeletal combined with } \mathrm{C}-\mathrm{H} \text { in-plane } \\
\text { deforming and stretching }\end{array}$ \\
\hline 1374 & 1373 & 1373 & 1373 & & & 1382 & & 1368 & 1376 & & 1376 & Aliphatic C-H stretching in methyl and phenol OH \\
\hline \multirow[t]{2}{*}{1328} & 1328 & 1327 & 1330 & & & & & & & & & $\begin{array}{l}\text { Condensation of guaiacyl unit and syringyl unit, } \\
\text { syringyl unit and CH2 bending stretching }\end{array}$ \\
\hline & & & & 1272 & 1256 & 1259 & 1253 & & & & & Guaiacyl ring breathing with $\mathrm{C}-\mathrm{O}$ stretching \\
\hline 1241 & 1238 & 1243 & 1240 & & & & & & & & & $\mathrm{C}-\mathrm{C}$ plus $\mathrm{C}-\mathrm{O}$ plus $\mathrm{C}-\mathrm{O}$ stretching \\
\hline 1158 & 1160 & 1161 & 1159 & & & & & & & & & $\begin{array}{l}\mathrm{C}-\mathrm{O}-\mathrm{C} \text { stretching in pyranose rings, } \mathrm{C}-\mathrm{O} \text { stretching } \\
\text { in aliphatic group }\end{array}$ \\
\hline 1055 & 1056 & 1057 & 1055 & & & & & & & & & $\begin{array}{l}\mathrm{C}-\mathrm{O} \text { deformation in primary alcohols, plus } \mathrm{C}-\mathrm{O} \\
\text { stretch unconjugated plus aromatic } \mathrm{C}-\mathrm{H} \text { in-plane } \\
\text { deformation }\end{array}$ \\
\hline 898 & 898 & 898 & 898 & & & & & & & & & $\mathrm{C}-\mathrm{H}$ stretching out of plane of aromatic ring \\
\hline 604 & 610 & 610 & 609 & & & & & & & & & $\mathrm{C}-\mathrm{OH}$ out of plane bending \\
\hline
\end{tabular}

$\mathrm{A}=$ Albizia; $\mathrm{G}=$ Gmelina; $\mathrm{M}=$ Mindi; $\mathrm{Mg}=$ Mangium

cies grown in West Java, Indonesia. Journal of the Korean Wood Science and Technology 43(2): 248-257. DOI: 10.5658/WOOD.2015.43.2.248

Fowles, M. 2007 Black carbon sequestration as an alternative to bioenergy. Biomass and Bioenergy 31(6): 426-432. DOI: 10.1016/j.biombioe.2007.01.012

Fuwape, J. A. 1996 Effects of carbonisation temperature on charcoal from some tropical trees. Bioresource Technology 57(1): 91-94. DOI: 10.1016/0960-8524(96)00027-2

Fuwape, J. A., and S. O. Akindele 1997 Biomass yield and energy value of some fast-growing multipurpose trees in Nigeria. Biomass and Bioenergy 12(2): 101-106. DOI: 10.1016/ S0961-9534(96)00061-X

Han, G. S., and B. R. Kim 2006 Characteristics of charcoal from wood pellet. Journal of the Korean Wood Science and Technology 34(3): 15-21.

Harrison, N. A., E. Boa, and M. L. Carpio 2003 Characterization of phytoplasmas detected in Chinaberry trees with symptoms of leaf yellowing and decline in Bolivia. Plant Pathology 52(2): 147-157. DOI: 10.1046/j.1365-3059.2003.00818.x

Kaltschmitt, M., H. Hartmann, and H. Hofbauer 2009 Energy from biomass. Fundamentals, techniques and procedures. 2nd ed. Springer, Berlin.

Kataki, R., and D. Konwer 2001 Fuelwood characteristics of some indigenous woody species of north-east India. Biomass and Bioenergy 20(1): 17-23. DOI: 10.1016/S09619534(00)00060-X

Kim, J. H., J. H. Jang, S. M. Kwon, F. Febrianto, and N. H. Kim 2012 Anatomical properties of major planted and promising species growing in Indonesia. Journal of the Korean Wood
Science and Technology 40(4): 244-256. DOI: 10.5658/ WOOD.2012.40.4.244

Kim, J. H., J. H. Jang, J. Y. Ryu, F. Febrianto, W. J. Hwang, and N. H. Kim 2014 Physical and mechanical properties of major planted and promising species grown in Indonesia (I). Journal of the Korean Wood Science and Technology 42(4): 467476. DOI: 10.5658/WOOD.2014.42.4.467

Kim, N.H., and R. B. Hanna 2006 Morphological characteristics of Quercus variabilis charcoal prepared at different temperatures. Wood Science and Technology 40(5): 392-401. DOI: 10.1007/s00226-005-0062-5

KSA 2011 KS E 3707: Determination of calorific value of coal and coke. Korean Standards Association.

KSA 2012 KS E ISO562: Hard coal and coke-Determination of volatile matter. Korean Standards Association.

KSA 2012 KS E ISO1171: Solid mineral fuels-Determination of ash content. Korean Standards Association.

Krisnawati, H., E. Varis, M. Kallio, and M. Kanninen 2011 Paraserianthes falcataria (L.) Nielsen: Ecology, silviculture and productivity. Center for International Forestry Research (CIFOR). Bogor, Indonesia. DOI: 10.17528/ cifor/003394

Kumar, R., and N. Chandrashekar 2013 Study on chemical, elemental and combustion characteristics of Lantana camara wood charcoal. Joumal of the Indian Academy of Wood Science 10(2): 134-139. DOI: 10.1007/s13196-013-0103-x

Kumar, R., F. Hu, C. A. Hubbell, A. Ragauskas, and C. E. Wyman 2013 Comparison of laboratory delignification methods, their selectivity, and impacts on physiochemical characteristics of cellulosic biomass. Bioresource Technology 130: 372-381. 
DOI:10.1016/j.biortech.2012.12.028

Kwon, S. M., N. H. Kim, and D. S. Cha 2009 An investigation on the transition characteristics of the wood cell walls during carbonization. Wood Science and Technology 43(5): 487-498. DOI: $10.1007 / \mathrm{s} 00226-009-0245-6$

Kwon, S. M., J. H. Jang, S. H. Lee, S. B. Park, and N. H. Kim 2013 Change of heating value, $\mathrm{pH}$ and FT-IR spectra of charcoal at different carbonization temperatures. Journal of the Korean Wood Science and Technology 41(5): 440-446. DOI: 10.5658/WOOD.2013.41.5.440

Liu, Z. J., B. H. Fei, Z. H. Jiang, and X. E. Liu 2014 Combustion characteristics of bamboo biochars. Bioresource Technology 167: 94-99. DOI: 10.1016/j.biortech.2014.05.023

Lohri, C. R., H. M. Rajabu, D. J. Sweeney, and C. Zurbrügga 2016 Char fuel production in developing countries: A review of urban biowaste carbonization. Renewable and Sustainable Energy Reviews 59: 1514-1530. DOI: 10.1016/j.rser.2016.01. 088.

Luo, Y., M. Durenkamp, M. De Nobili, Q. Lin, and P. C. Brookes 2011 Short term soil priming effects and the mineralisation of biochar following its incorporation to soils of different $\mathrm{pH}$. Soil Biology and Biochemistry 43(11): 2304-2314. DOI: 10.1016/j.soilbio.2011.07.020

Marquez, F., F. Correa, C. Glauco, R. Zanzi, J. G. Rutiaga, and L. Leonardo 2015 Pyrolytic degradation studies of Acacia mangium wood. BioResources 10(1):1825-1844. DOI: 10.15376/ biores.10.1.1825-1844

Martawijaya, A., I. Kartasujana, Y. I. Mandang, S. A. Prawira, and K. Kadir 1989 Indonesian wood atlas, Volume II. Ministry of Forestry, Agency for Forestry Research and Development, Forest Products Research and Development Centre. Bogor, Indonesia.

McNaught, A. D., and A. Wilkinson 1997 IUPAC compendium of chemical terminology. 2nd Ed., Blackwell Science. Oxpord, UK.

Ministry of Forestry, Republic of Indonesia 2014 Ministry of forestry statistics 2013. http://www.dephut.go.id/uploads/files/2 fba7c7da8536e31671e3bb84f141195.pdf

Muller, G., C. Schopper, H. Vos, A. Kharazipour, and A. Polle 2009 FTIR-ATR Spectroscopic analyses of changes in wood properties during particle-and fibreboard production of hard-and softwood trees. BioResources 4(1): 49-71.

Nishimiya, K., T. Hata, Y. Imamura, and S. Ishihara 1998 Analysis of chemical structure of wood charcoal by X-ray photoelectron spectroscopy. Journal of Wood Science 44(1): 56-61. DOI: 10.1007/BF00521875

Park, S. H., J. H. Jang, W. Hidayat, Y. Qi, F. Febrianto, and N. H. Kim NH 2015 Combustion properties of major wood species planted in Indonesia. Journal of the Korean Wood Science and Technology. 43(6): 768-776. DOI: 10.5658/WOOD.2015. 43.6.768

Park, S. H., J. H. Jang, Y. Qi, W. Hidayat, W. J. Hwang, F. Febrianto, and N. H. Kim. 2016 Color change of major wood species planted in Indonesia by ultraviolet radiation. Journal of the Korean Wood Science and Technology 44(1): 9-18. DOI: 10.5658/WOOD.2016.44.1.9

Pereira, B. L. C., A. C. O. Carneiro, A. M. M. L. Carvalho, J. L. Colodette, A. C. Oliveira, and M. P. F. Fontes 2013 Influence of chemical composition of Eucalyptus wood on gravimetric yield and charcoal properties. BioResources 8(3): 45744592. DOI: 10.15376/biores.8.3.4574-4592

TAPPI 2006 TAPPI 435: Hydrogen ion concentration $(\mathrm{pH})$ of paper extracts (hot extraction method). Technical Association for Paper and Pulp Industries (TAPPI) Publication, Atlanta (USA).

Wu, J., K. Fukazawa, and J. Ohtani 1992 Distribution of syringyl and guaiacyl lignins in hardwoods in relation to habitat and porosity form in wood. Holzforschung 46: 181-185. DOI 10.1515/hfsg.1992.46.3.181

Yamashita, N., S. Ohta, and A. Hardjono 2008 Soil changes induced by Acacia mangium plantation establishment: Comparison with secondary forest and Imperata cylindrica grassland soils in South Sumatra, Indonesia. Forest Ecology and Management $\mathbf{2 5 4}(2): \quad 362-370 . \quad$ DOI: $10.1016 / j$ foreco.2007.08.012

Yan, W., T. C. Acharjee, C. J. Coronella, and V. R. Vasquez 2009 Thermal pretreatment of lignocellulosic biomass. Environmental Progress \& Sustainable Energy 28(3): 435440. DOI: 10.1002/ep.10385

Yang, H., R. Yan, H. P. Chen, D. H. Lee, and C. G. Zheng 2007 Characteristics of hemicellulose, cellulose and lignin pyrolysis. Fuel 86: 1781-1788. DOI: 10.1016/j.fuel.2006.12.013 